\title{
EFEKTIFITAS PENYULUHAN DARING PADA MASA PANDEMI COVID-19 TERHADAP TINGKAT PENGETAHUAN REMAJA PEREMPUAN TENTANG PENCEGAHAN KEPUTIHAN
}

\author{
Yogho Prastyo \\ Jurusan Kebidanan Fakultas Ilmu Kesehatan Universitas Borneo Tarakan \\ Email : yoghoprastyo@borneo.ac.id
}

\begin{abstract}
Abstrak
Salah satu masalah kesehatan reproduksi yang sering dialami oleh para remaja perempuan adalah masalah keputihan (flour albus). Dampak pandemi Covid-19 memaksa pendidikan dan pembelajaran dilakukan secara daring termasuk pendidikan kesehatan dengan metode penyuluhan. Penelitian ini bertujuan untuk mengetahui efektifitas penyuluhan daring pada masa pandemi Covid-19 terhadap tingkat pengetahuan remaja perempuan tentang pencegahan keputihan. Jenis rancangan penelitian eksperimen yang digunakan adalah rancangan pra-eksperimen dengan rancangan One Group Pretest Posttest. Desain penyuluhan dalam bentuk interaktif, menggunakan melalui Zoom Meeting. Populasi penelitian ini adalah mahasiswa semester 3 Program Studi DIII Kebidanan Fakultas Ilmu Kesehatan Universitas Borneo Tarakan TA 2020/2021. Data dikumpulkan dengan metode kuesioner. Hasil penelitian menunjukkan bahwa terdapat perbedaan yang sangat signifikan yaitu sebagian besar mahasiswa memiliki tingkat pengetahuan baik menjadi sebanyak 51,6\% responden. Sehingga disimpulkan bahwa terdapat keefektifan penyuluhan daring pada masa pandemi Covid-19 terhadap tingkat pengetahuan remaja perempuan tentang pencegahan keputihan pada mahasiswa DIII Kebidanan Universitas Borneo Tarakan
\end{abstract}

Kata Kunci :Remaja Perempuan, Pengetahuan, Keputihan, Covid-19, Daring

\begin{abstract}
Effectiveness Of Daily Counseling In The Covid-19 Pandemic Period On Knowledge Levels Of Young Adolescents About White Prevention. One of the reproductive health problems that adolescents often experience is flour albus. The Covid-19 pandemic impact has forced education and learning to be carried out online, including health education using extension methods. This study aims to determine the effectiveness of online counseling during the Covid-19 pandemic on young women's level of knowledge about preventing vaginal discharge. This type of experimental research design was a pre-experimental design with a one-group pretest-posttest design and an outreach design in an interactive form through Zoom Meeting. The research population was the 3rd-semester students of the Diploma Midwifery Study Program, Faculty of Health Sciences, University of Borneo Tarakan, the school year 2020/2021. Data was collected using a questionnaire method. The results showed that there was a very significant difference in which most students had an adequate level of knowledge to as many as $51.6 \%$ of respondents. So it can be concluded that online counseling during the pandemic requires Midwifery Diploma students' acquaintance about preventing vaginal discharge at the Borneo University of Tarakan.
\end{abstract}

Keywords: Young women, Knowledge, Flour Albus, Covid-19, Online 


\section{Pendahuluan}

Masa remaja merupakan suatu periode transisi antara masa kanak-kanak dan masa dewasa, yang mengalami serangkaian perkembangan biologis yang meliputi perubahan anatomi dan fungsional, psikologis, kognitif, sosial, dan emosional, sebagai persiapan memasuki masa dewasa (Wong, 2009; Notoatmodjo, 2007).

Menurut Kumalasari (2012) remaja perempuan di Indonesia mengalami berbagai masalah kesehatan reproduksi. Salah satu masalah kesehatan reproduksi yang sering dialami oleh para remaja perempuan adalah masalah keputihan atau fluor albus.

Hal ini ditunjang oleh faktor Indonesia yang beriklim tropis, udara panas dan cenderung lembab terutama di bagian tubuh yang tertutup dan lipatan-lipatan kulit, seperti daerah alat kelamin. Kondisi ini dapat menyebabkan mikroorganisme jahat, terutama jamur mudah berkembang biak, yang akhirnya bisa menimbulkan keputihan (Kusmiran, 2012)

Penyebab keputihan $70 \%$ karena jamur dan parasit atau protozoa (Trichomonas vaginalis, serta infeksi jamur Candida albicans) (Jawetz, 2008). Perilaku buruk dalam menjaga kebersihan genitalia dapat menjadi pencetus timbulnya infeksi yang menyebabkan keputihan tersebut. Jadi, perilaku hidup bersih dan sehat dalam menjaga kebersihan genitalia eksterna perempuan merupakan faktor penting dalam pencegahan keputihan.

Beberapa faktor penghambat untuk berperilaku sehat dalam upaya pencegahan keputihan pada remaja, diantaranya kurangnya pengetahuan remaja tentang pencegahan keputihan, sikap yang tidak tepat yang memperlemah motivasi seseorang untuk berperilaku hidup sehat dalam upaya pencegahan keputihan. Remaja yang belum mengerti mengenai pencegahan keputihan maka perlu dilakukan pendidikan kesehatan.

Meningkatkan pengetahuan remaja perempuan terhadap pencegahan keputihan dapat dilakukan dengan melakukan pendidikan kesehatan dengan metode penyuluhan. Hal yang menjadi perhatian besar saat ini adalah dampak pandemi Covid-19 yang sedang melanda dunia, termasuk Indonesia. Dampak pandemi Covid-19 memaksa pendidikan dan pembelajaran dilakukan secara daring (online) termasuk pendidikan kesehatan dengan metode penyuluhan (Sadikin, 2020). Tentunya hal ini agar tetap sinergi terhadap visi Universitas Borneo Tarakan dalam penyelenggaraan pendidikan. Namun, yang menjadi permasalahan adalah kekurangan dan 
keterbatasan sistem daring ini.

Tujuan dilakukan penelitian ini adalah untuk mengetahui efektifitas penyuluhan daring pada masa pandemi Covid-19 terhadap tingkat pengetahuan remaja perempuan tentang pencegahan keputihan.

\section{Metode}

Penelitian ini adalah penelitian eksperimental. Jenis rancangan penelitian eksperimen yang digunakan adalah rancangan pra-eksperimen dengan rancangan One Group Pretest Posttest.

Pengukuran dilakukan dalam dua tahap. Tahap pertama dilakukan sebelum diberi penyuluhan keputihan dengan kuesioner pengetahuan dan tahap yang kedua dilakukan setelah penyuluhan.

Penelitian ini akan dilaksanakan pada bulan September - Oktober tahun 2020. Desain penyuluhan dalam bentuk interaktif, penyuluhan dilaksanakan tanpa tatap-muka menggunakan melalui media daring yaitu Zoom Meeting. Populasi mahasiswa semester 3 Program Studi DIII Kebidanan Fakultas Ilmu Kesehatan Universitas Borneo Tarakan TA 2020/2021 sedangkan sampel penelitian ini 31 mahasiswa dengan teknik penarikan sampel adalah accidental sampling. Kelompok populasi ditetapkan karena belum mendapatkan pendidikan kesehatan reproduksi secara formal di pendidikan tinggi. Data dikumpulkan dengan metode kuesioner, Uji validitas dan reliabilitas instrumen dilakukan dengan uji korelasi dan reliabilitas dengan menggunakan alpha cronbach. Kuesioner yang diuji validitasnya berjumlah 40 pertanyaan yang menyangkut beberapa kisi-kisi terkait analgetik pada 47 responden. Hasil uji validitas menunjukkan bahwa dari 40 item pertanyaan yang diuji hanya 17 item yang valid. Uji reliabilitas menunjukkan nilai alpha cronbach sebesar 0,674. Hasil ini menunjukkan bahwa pertanyaan yang akan digunakan dalam kuesioner dinilai reliabel sebagai alat ukur pengetahuan.

Kuesioner digunakan untuk menguji pengetahuan mahasiswa terhadap materi penyuluhan. Kuesioner diberikan dua kali, yaitu pre-test dan post-test, untuk mengidentifikasi perubahan pengetahuan mahasiswa sebelum dan sesudah penyuluhan diberikan. Kuesioner tingkat pengetahuan remaja perempuan tentang pencegahan keputihan sebanyak 17 soal, aspek pengukuran meliputi pengertian, penyebab, gejala dan pencegahan keputihan. Kuesioner dibagikan kepada responden menggunakan Google Form.

Efektivitas penyuluhan daring ditinjau dari dua pendekatan, yaitu: 1) membandingkan distribusi data sebelum penyuluhan (pre-test) dan setelah penyuluhan diberikan (post-test). 
2) menggunakan Uji-T untuk menguji hipotesis penelitian. Adapun hipotesis dalam penelitian: ada perbedaan tingkat pengetahuan remaja perempuan tentang pencegahan keputihan. Hipotesis nol dalam penelitian ini adalah inversi dari hipotesis dalam penelitian ini seperti yang telah dinyatakan sebelumnya.

\section{Hasil}

Hasil distribusi frekuensi pada pre-test dan post-test tingkat pengetahuan remaja perempuan tentang pencegahan keputihan dianalisis dan disajikan pada Tabel 1.
Tabel 1. Distribusi frekuensi pada pre-test dan post-test tingkat pengetahuan remaja perempuan tentang pencegahan keputihan

\begin{tabular}{ccccc}
\hline \multirow{2}{*}{$\begin{array}{c}\text { Tingkat } \\
\text { Pengeta } \\
\text { huan }\end{array}$} & $\begin{array}{c}\text { Freku } \\
\text { ensi } \\
\text { (f) }\end{array}$ & $\begin{array}{c}\text { Persen } \\
\text { tase } \\
(\%)\end{array}$ & $\begin{array}{c}\text { Freku } \\
\text { ensi } \\
(\mathrm{f})\end{array}$ & $\begin{array}{c}\text { Persen } \\
\text { tase } \\
(\%)\end{array}$ \\
\hline Baik & 9 & 29 & 16 & 51,6 \\
Cukup & 18 & 58,1 & 14 & 45,2 \\
Kurang & 4 & 12,9 & 1 & 3,2 \\
\hline Total & 31 & 100 & 47 & 100 \\
\hline
\end{tabular}

Analisis bivariat menggunakan Uji Paired Sampel $t$-test dilihat pada tabel 2 berikut:

Tabel 2. Hasil Uji Statistik Paired Sample T-Test Pada Pre-Test Dan Post-Test Tingkat Pengetahuan Remaja Perempuan Tentang Pencegahan Keputihan.

\begin{tabular}{|c|c|c|c|c|c|c|c|}
\hline \multirow[b]{2}{*}{ Sikap } & \multirow[b]{2}{*}{ Mean } & \multirow[b]{2}{*}{$\mathrm{SD}$} & \multicolumn{2}{|c|}{ IK $95 \%$} & \multirow[b]{2}{*}{$\mathrm{t}$} & \multirow[b]{2}{*}{ P-value } & \multirow[b]{2}{*}{ Keterangan } \\
\hline & & & $\begin{array}{c}\text { Lowe } \\
\text { r }\end{array}$ & Upper & & & \\
\hline $\begin{array}{l}\text { Pretest- } \\
\text { posttest }\end{array}$ & $-1,000$ & 2,449 & $\begin{array}{c}- \\
1,898\end{array}$ & $-0,102$ & $-2,273$ & 0,030 & Ada Pengaruh \\
\hline
\end{tabular}

\section{Pembahasan}

\section{Pengetahuan Penyuluhan Daring}

Pengetahuan diukur dengan menggunakan kuesioner sebanyak dua kali, yaitu sebelum dan setelah penyuluhan. Sebelum penyuluhan, diketahui bahwa sebagian besar pengetahuan mahasiswa sebanyak $18(58,1 \%)$ responden dalam kategori Cukup.

Menurut Notoatmodjo (2010), pengetahuan merupakan hasil dari tahu yang terjadi setelah orang melakukan pengindraan terhadap objek tertentu dan pengetahuan hanya akan terwujud jika manusia tersebut adalah bagian dari objek itu sendiri. Dalam penelitian ini, pengetahuan remaja perempuan tentang pencegahan keputihan yang diukur mencakup pengetahuan tentang pengertian, penyebab, gejala dan pencegahan keputihan, Penginderaan dalam hal ini berkaitan dalam hal 
mendengar dan melihat karena dalam penelitian ini mahasiswa bisa saja terpapar informasi yang sebelumnya pernah didapatkan dari berbagai media yang ada.

Mahasiswa yang masih memiliki pengetahuan kurang mengenai bounding attachment pada penelitian ini dapat dipengaruhi oleh beberapa faktor. Menurut Wawan dan Dewi (2010), pengetahuan dipengaruhi oleh beberapa faktor diantaranya pendidikan, pekerjaan, umur, lingkungan, sosial budaya dan informasi. Informasi dalam penelitian ini merupakan penyuluhan yang masih terdapat beberapa mahasiswa yang belum pernah mendengar dan mengetahui mengenai pentingnya pencegahan keputihan pada remaja sehingga pengetahuan yang didapatkan pun masih kurang.

Setelah penyuluhan, terjadi perbedaan yang sangat signifikan yaitu sebagian besar mahasiswa memiliki tingkat pengetahuan baik menjadi sebanyak $16(51,6 \%)$ responden. Pengetahuan dipengaruhi oleh beberapa faktor diantaranya pendidikan, pekerjaan, umur, lingkungan, sosial budaya dan informasi.

Menurut Firyal (2020) aspek pengetahuan dapat dicapai dengan penerapan pembelajaran daring, terutama dalam masa pandemic Covid19 sesuai anjuran pemerintah.

. Penelitian Kharisma (2020) menjelaskan bahwa hasil gambaran pembelajaran daring memberikan dampak positif terhadap pengetahuan serta pelaksanaan pembelajaran daring sangat direkomendasikan dalam upaya pencegahan penyebaran virus Covid-19.

Dalam penelitian ini pemberian informasi melalui penyuluhan dengan menggunakan media daring. Penyuluhan tersebut merupakan salah satu cara yang digunakan untuk menambah pengetahuan dengan tujuan mengubah atau mempengaruhi perilaku manusia secara individu, kelompok maupun masyarakat.

\section{Efektifitas penyuluhan daring pada masa pandemi Covid-19}

Efektifitas yang dimaksud dalam penggunaan aplikasi ini yaitu peningkatan pengetahuan, atau individu memperoleh atau menambah informasi dan pemahaman terhadap pengetahuan tertentu.

Berdasarkan hasil analisis data dari uji statistik yaitu Uji Paired Sampe T-Test diperoleh $\mathrm{T}_{\text {hitung }}-2,273$ dan nilai signifikansi sebesar $\quad 0,030 \quad(P$-value $<0,05) . \quad$ Dengan demikian, jika $P$-value $<0,05$ maka terdapat keefektifan penyuluhan terhadap pengetahuan remaja perempuan tentang pencegahan keputihan mahasiswa DIII Kebidanan Universitas Borneo Tarakan. 
Penyuluhan daring membutuhkan usaha yang lebih besar dari penyuluh dan mahasiswa sebagai kelompok-sasaran, tidak semudah dan sesederhana yang dibayangkan. Melalui penyuluhan daring penyuluh dituntut menciptakan lingkungan belajar yang interaktif (Oktavian \& Aldya, 2020).

Pemanfaatan media daring pada dasarnya dimaksudkan untuk membantu agar kegiatan penyuluhan lebih efektif mencapai tujuan dan efisien dalam hal tenaga, waktu dan biaya (Falahudin, 2014). Selain itu, penyampaian penyuluhan kepada mahasiswa karena mahasiswa sudah mulai terbiasa menggunakan media daring pengganti tatap muka langsung.

\section{Kesimpulan}

Berdasarkan hasil analisis, maka dapat ditarik kesimpulan bahwa terdapat keefektifan penyuluhan daring pada masa pandemi Covid19 terhadap tingkat pengetahuan remaja perempuan tentang pencegahan keputihan pada mahasiswa DIII Kebidanan Universitas Borneo Tarakan.

\section{Ucapan Terimakasih}

Ucapan terimakasih disampaikan kepada DIPA/PNBP Universitas Borneo Tarakan yang telah memberi kesempatan dan dana sehingga penelitian ini dapat selesaikan.

\section{Referensi}

Falahudin, I. (2014). Pemanfaatan media dalam pembelajaran. Jurnal Lingkar Widyaiswara, 1(4), 104-117.

Firyal, R. A. (2020). Pembelajaran Daring dan Kebijakan New Normal Pemerintah. https://doi.org/10.31228/osf.io/yt6qs

Jawetz, E., Melnick, G. E., \& Adelberg, C. A. (2008). Mikrobiologi kedokteran. Edisi I. Diterjemahkan oleh Penerjemah Bagian Mikrobiologi Fakultas Kedokteran Universitas Airlangga.

Kharisma, N., Roesminingsih, M., \& Suhanadji, S. (2020). Gambaran Kebutuhan Pembelajaran Daring PKBM Budi Utama Surabaya Pada Masa Pandemi Covid-19. Jurnal Pendidikan Nonformal, $\quad$ 15(1), 38-44. doi:http://dx.doi.org/10.17977/um041v1 5ilp38-45

Kumalasari, I., \& Andhyantoro, I. (2012).

Kesehatan reproduksi untuk mahasiswa kebidanan dan keperawatan. Jakarta: Salemba Medika, 18-9.

Kusmiran, Eny,Reproduksi Remaja dan Wanita, (2012). Jakarta:Salemba Medika.

Notoatmodjo, S. (2007). Tumbuh Kembang 
Remaja dan Permasalahannya. Jakarta: Rineka Cipta.

Notoatmodjo, S. (2010). Metodologi penelitian kesehatan.

Oktavian, R., \& Aldya, R. F. (2020). Efektivitas Pembelajaran Daring Terintegrasi di Era Pendidikan 4.0. Didaktis: Jurnal Pendidikan dan Ilmu Pengetahuan, 20(2).

Sadikin, A., \& Hamidah, A. (2020).
Pembelajaran Daring di Tengah Wabah Covid-19:(Online Learning in the Middle of the Covid-19 Pandemic). Biodik, 6(2), 214-224.

Wawan, A., M, Dewi (2010). Teori \& Pengukuran Pengetahuan, Sikap, dan Perilaku Manusia. Yogyakarta: Nuha Medika

Wong, D. L. (2009). Buku ajar keperawatan pediatrik vol 1 wong. EGC. 